\title{
Correction: Riluzole reduces amyloid beta pathology, improves memory, and restores gene expression changes in a transgenic mouse model of early-onset Alzheimer's disease
}

Masahiro Okamato ${ }^{1,2}$, Jason D. Gray ${ }^{1}$, Chloe S. Larson ${ }^{1,3,4}$, Syed Faraz Kazim³,4 Hideaki Soya ${ }^{2}$, Bruce S. McEwen ${ }^{1}$ and Ana C. Pereira,

\section{Correction to: Translational Psychiatry; https://doi.org/10.1038/s41398-018-0201-z; Published online 14 August 2018.}

The author's name was spelled incorrectly as "Masahir Okamoto". This has been updated to "Masahiro Okamoto" in the HTML and PDF of the article.
Published online: 04 February 2019

Correspondence: Ana C. Pereira (ana.pereira@mssm.edu)

'Laboratory of Neuroendocrinology, The Rockefeller University, New York, NY 10065, USA

${ }^{2}$ Laboratory of Exercise Biochemistry and Neuroendocrinology, Faculty of

Health and Sports Sciences, University of Tsukuba, Tsukuba, Ibaraki 305-8574, Japan

${ }^{3}$ Department of Neurology, Icahn School of Medicine at Mount Sinai, New York, NY 10029, USA

${ }^{4}$ Fishberg Department of Neuroscience, Friedman Brain Institute, Icahn School of Medicine at Mount Sinai, New York, NY 10029, USA

These authors contributed equally: Masahiro Okamoto, Jason D. Gray.

(c) (i) Open Access This article is licensed under a Creative Commons Attribution 4.0 International License, which permits use, sharing, adaptation, distribution and reproduction c. in any medium or format, as long as you give appropriate credit to the original author(s) and the source, provide a link to the Creative Commons license, and indicate if changes were made. The images or other third party material in this article are included in the article's Creative Commons license, unless indicated otherwise in a credit line to the material. If material is not included in the article's Creative Commons license and your intended use is not permitted by statutory regulation or exceeds the permitted use, you will need to obtain permission directly from the copyright holder. To view a copy of this license, visit http://creativecommons.org/licenses/by/4.0/. 